\title{
IMPLEMENTATION OF THINK TALK WRITE (TTW) LEARNING MODEL TO INCREASE LEARNING RESULTS WRITE POETRY ON GRADE 5 ELEMENTARY SCHOOL
}

\author{
Syaiful Bahri \\ syaifulbahri@stkippgrisumenep.ac.id \\ Program Studi Pendidikan Guru Sekolah Dasar \\ STKIP PGRI Sumenep
}

\begin{abstract}
The aim of research was to know the implementation of Think Talk Write Learning Model to increasing Indonesian learning results on poetry writing subject in fifth class of elementary school. The method of this research was classroom action research that used two cycles. Every cycles were four phases, they are: (1) plan; (2) action; (3) observe; (4) Reflection. The subjects of research are the students of grade V of the State Elementary School of Batu Belah Timur I Lesson Year 2017/2018. The result showed that pre-cycle in cognitive aspects got 45,33\%, first cycle $70 \%$ and second cycle $90 \%$. The cognitive result averages in pre cycles were $67.00 \%$. After the students were given first treatment, the cognitive result averages have increased to be $79,52 \%$. In second cycle increased to be more than first cycle, it was $98,33 \%$. Meanwhile, in psicomotoric aspects of pre-cycle showed that the results were $64,50 \%$. After the students got first treatment, the result of psicomotoric aspects increased to be $83,00 \%$. Then, the second cycle were to be $98,00 \%$.
\end{abstract}

Keywords: Think Talk Write (TTW), writing poetry, learning results

\section{IMPLEMENTASI MODEL PEMBELAJARAN THINK TALK WRITE (TTW) UNTUK PENINGKATAN HASIL BELAJAR MENULIS PUISI SISWA KELAS V SEKOLAH DASAR}

\begin{abstract}
Abstrak: Penelitian ini bertujuan untuk mengetahui implementasi model pembelajaran Think Talk Write dalam meningkatkan hasil belajar bahasa Indonesia materi menulis puisi siswa kelas V Sekolah Dasar. Metode yang digunakan dalam penelitian ini adalah penelitian tindakan yang dilakukan dalam dua siklus, setiap siklus terdiri dari tahapan sebagai berikut, (1) perencanaan; (2) pelaksanaan; (3) pengamatan; dan (4) refleksi. Subjek penelitian ini adalah siswa kelas V Sekolah Dasar Negeri Batu Belah Timur I tahun pelajaran 2017/2018. Hasil penelitian ini menunjukkan bahwa Pra tindakan memperoleh tingkat ketercapaian klasikal pada aspek kognitif sebesar 45,33\%, dan tindakan I sebesar 70\% sedangkan pada tindakan II sebesar 90\%. Aspek rata-rata nilai afektif pada pra tindakan menunjukkan 67,00, setelah dilakukan tindakan I rata-rata nilai afektif meningkat menjadi 79,52 dan mengalami peningkatan menjadi 98,33 pada tindakan II, sedangkan aspek psikomotorik rata-rata nilai psikomotor pada pra tindakan menunjukkan 64,50, setelah dilakukan tindakan I rata-rata nilai psikomotor meningkat menjadi 83,00 dan mengalami peningkatan menjadi 98,00 pada tindakan II.
\end{abstract}

Kata Kunci: Think Talk Write (TTW), Menulis Puisi, Hasil Belajar 


\section{Syaiful, Implementasi Model Pembelajaran Think...}

\section{PENDAHULUAN}

Problematika pendidikan pada dasarnya selalu mencul bersamaan dengan meningkatnya kemampuan siswa, situasi dan kondisi lingkungan, pengaruh informasi dan kebudayaan serta pengaruh ilmu pengetahuan dan teknologi. Cukuplah wajar jika dunia pendidikan di Indonesia mendapatkan tempat teratas dan menjadi perhatian khusus Negara. Peningkatan kemampuan sumber daya manusia merupakan suatu keharusan bagi bangsa Indonesia guna memiliki kemampuan kompetitif.

Dalam rangka peningkatan kualitas sumber daya manusia perlu adanya pembentukan watak dan karakter manusia, pendidikan memiliki peran yang strategis. Pembentukan watak dan karakter harus dilakukan secara integratif. Salah satu di antara sekian banyak hal yang dapat dialakukan guna membangun dan membentuk karakter manusia adalah dengan kegiatan menulis. Kegiatan menulis merupakan kegiatan yang dilakukan seseorang setelah membaca dan mendiskusikan suatu hal. Selain dari itu, kegiatan menulis juga berarti mengungkapkan dan mentransformasikan pikiran dan pendapat yang dilandasi oleh fakta dan berbagai data yang falid.

Hasil belajar bahasa Indonesia siswa kelas V SD Negeri Batu Belah Timur I Kecamatan Dasuk Kabupaten Sumenep sebelum dilakukan tindakan masih rendah. Rendahnya hasil belajar itu dapat dilihat dari banyaknya siswa yang mendapat nilai di bawah kreteria ketuntasan minimal (KKM). Ketuntasan belajar klasikal pada aspek kognitif sebesar 45,33\%, dan ketuntasan aspek afektif sebesar 67,00\%, sedangakan ketuntasan klasikal aspek psikomotorik sebesar 64,50\%.

Lubis (1997) berpendapat bahwa kegiatan menulis merupakan kegiatan yang dilakukan seseorang guna mengungkapkan tentang manusia, tentang kehidupan dan pengalaman, tentang pikiran, dan kebahagiaan dan nestapa. Kemudian juga bagaimana mengungkapkan dan mentransformasikan alam beserta isinya, tidak hanya anak manusia tetapi juga tentang langit saat malam yang bertabur bintang dan rembulan. Kegiatan menulis dapat berupa apa saja yang dapat menimbulkan keharuan batin, dan mendorong untuk berpikir, mencernakan dan mempublikasikan apa yang dilihat, dirasa, didengar dan yang dialami, barulah kemudian pada akhirnya mampu mencipta.

Kehidupan nyata bagi sebagian orang mungkin terlewati begitu saja, tapi tidak untuk mereka yang gemar mengurai kehidupan ini dengan berbagai fenomenanya dengan tulisan. Berangkat dari pemikiran itulah maka siswa diharapkan menjadi salah satu dari sekian banyak orang yang peduli terhadap gejala-gejala kehidupan dunia ini sehingga mampu berkontemplasi dan membangun dirinya menjadi manusia yang terdidik dan kompetitif. Kegiatan menulis tentu sangat berbeda dengan kegiatan berbicara, di samping tuntutan pada setiap kalimat-kalimatnya yang harus kohesif dan koheren juga harus mampu membina dunia sendiri.

Kehidupan nyata tersebut di atas jika ditranformasikan dengan bahasa-bahasa yang menarik dengan lebih menekankan pada kepadatan makna dan simbolitas tentu akan lebih bernilai. Oleh karena pemikiran tersebutlah karya sastra yang disebut sebagai 


\section{Syaiful, Implementasi Model Pembelajaran Think...}

puisi yang merupakan hasil cipta manusia yang terdiri atas satu atau beberapa larik (baris) yang memperhatikan pertalian makna itulah yang menjadi titik tekan utama yang dapat dilakukan guna membangun daya kompetisi manusia Indonesia terutama para siswa.

Kegiatan menulis puisi yang dilakukan oleh para siswa tentu membutuhkan bimbingan dan pengarahan secara continue. Dibutuhkan penerapan model pembelajaran yang baik dan sekaligus memberdayakan para siswa, sehingga hasil dari kegiatan menulis tersebut merupakan hasil cipta karya yang berkualitas dan benarbenar dari siswa.

Shoimin (2017) berpendapat Think Talk Write merupakan suatu model pembelajaran untuk melatih keterampilan peserta didik dalam menulis. Think Talk Write menekankan perlunya peserta didik mengomunikasikan hasil pemikirannya dan mengimplementasikan dalam bentuk karya. Think artinya berpikir. Talk artinya berbicara, sedangkan Write artinya menulis, Oleh sebab itu, model think talk write merupakan perencanaan dan tindakan yang cermat mengenai kegiatan pembelajaran, yaitu melalui kegiatan berpikir (Think), berbicara/berdiskusi, bertukar pendapat (Talk), dan menulis hasil diskusi (Write) agar kompetensi yang diharapkan tercapai.

Model pembelajaran Think Talk Write (TTW) menitikberatkan pada proses literasi dan menelaah bahan ajar yang deberikan oleh guru. Setelah siswa melakaukan proses literasi maka siswa membuat catatan kecil. Ketika siswa membuat catatan kecil inilah akan terjadi proses berpikir (Think). Setelah itu, peserta didik berusaha untuk menyelesaikan masalah yang ada pada bahan ajar tersebut secara individu. Fase berikutnya, siswa melakukan diskusi dengan teman satu grup untuk membahas hasil catatan (Talk). Selanjutnya siswa secara individu merumuskan imajinasi dalam bentuk tulisan (Write) dengan menggunakan bahasanya sendiri.

Melalui penerapan model pembelajaran Tink Talk Write (TTW) diharapkan mampu meingkatkan hasil belajar menulis puisi siswa kelas V SDN Batu Belah Timur Kecamatan Dasuk Kabipaten Sumenep.

\section{METODE}

Penelitian ini termasuk jenis Penelitian Tindakan Kelas (PTK) atau Classroom Action Research (CAR). PTK ini ingin mengungkap peningkatan kemampuan siswa pada materi apresiasi puisi. Ciri yang menandakan PTK adalah adanya tindakan dalam setiap perlakuan.

Arikunto (2009) mengungkapkan penelitian tindakan kelas merupakan kegiatan penelitian yang dilakukan di dalam kelas. Penelitian tindakan kelas merupakan salah satu jenis dari pendekatan kualitatif yang dilakukan dengan bentuk siklus atau melingkar (cyclical), bukan linier seperti kuntitatif.

Berdasarkan hal tersebut, dalam penelitian ini akan dibagi dalam beberapa tindakan yang masing-masing menempuh tahapan tertentu. Setiap tindakan akan 


\section{Syaiful, Implementasi Model Pembelajaran Think...}

dilaksanakan sesuai dengan perubahan yang ingin dicapai untuk melihat adanya peningkatan kemapuan dalam mengapresiasi puisi.

Adapun tindakan yang dilakukan semata-mata merupakan kelanjutan dari penelitian eksperimen, sebab tujuan dari penelitian tindakan adalah mengetahui dampak dari suatu perlakuan, yaitu mencobakan sesuatu, lalu mencermati akibat dari perlakuan tersebut.

Dalam penelitian ini peneliti berpartisipasi aktif dan terlibat langsung dalam proses penelitian dari awal sampai penelitian berakhir. Setiap tahapan tindakan yang dilakukan peneliti senantiasa menyesuaikan dengan langkah-langkah penting dalam PTK model tindakan di atas, yakni perencanaan, tindakan, observasi dan refleksi.

Tahapan-tahapan pada tiap tindakan-tindakan tersebut akan diuraikan sebagai berikut.

\section{Perencanaan}

Peneliti dapat melakukan persiapan demi kelancaran dan keberhasilan dalam kegiatan penelitian tindakan kelas, antara lain :

a) Melaksanakan koordinasi dengan kepala sekolah dan guru mata pelajaran.

b) Mengidentifikasi permasalahan pembelajaran di kelas yang menjadi objek penelitian.

c) Menentukan satu permasalahan dari berbagai masalah yang telah teridentifikasi, untuk kemudian ditetapkan sebagai objek penelitian.

d) Menyusun skenario penelitian yang meliputi :

- Materi pelajaran yang akan diteliti.

- Kegiatan penelitian, melalui persiapan hingga penyusunan laporan.

- Membuat instrumen penelitian yang akan digunakan.

- Menentukan waktu penelitian.

- Mendiskusikan skenario penelitiandengan mempertimbangkan segala masukan dan kritik.

Dalam tahap perencanaan, peneliti melakukan refleksi awal dengan merumuskan rencana tindakan yang diharapankan dapat memberikan dampak poisitif dan upaya memberikan minat serta motivasi belajar siswa. Pada tahap ini kegiatan yang dilakukan antara lain dengan menyusun RPP, menyiapkan sarana dan prasarana yang di gunakan, merancang media dan sumber belajar, membuat lembar kerja siswa, menyiapkan perangkat tes akhir, menyusun instrument observasi bagi kegiatan guru dan kegiatan siswa, catatan lapangan dan lembar pengamatan.

\section{Pelaksanaan Tindakan}

Pada tahapan pelaksanaan tindakan ini, kegiatan yang dilakukan peneliti yaitu melaksanakan pembelajaran pada mata pelajaran bahasa Indonesia dengan kompetensi dasar menulis kreatif puisi berkenaan dengan keindahan alam melalui penerapan model pembelajaran kontekstual dengan Pendekatan Inquiri. 


\section{Syaiful, Implementasi Model Pembelajaran Think...}

\section{Observasi}

Selama pelaksanaan dapat digunakan lembar observasi untuk mengamati segala kegiatan yang dilaksanakan oleh guru dan siswa selama proses pembelajaran berlangsung. Kegiatan penggunaan lembar observasi penting digunakan untuk bahan refleksi guna mengetahui proses perlakuan yang muncul.

Dalam pada itu, peneliti dapat dibantu oleh pihak lain yang bertindak sebagai observer yang melakukan observasi di luar maupun di dalam kelas.

\section{Refleksi}

Setelah selesai melaksanakan tindakan, maka dilakukanlah refleksi atau pantulan untuk mengemukakan kembali apa yang sudah terjadi. Kegiatan refleksi berarti pula memantulkan kembali seperti sinar matahari yang kemudian memancar pada kaca dan kemudian dipantulkan lagi. Di dalam refleksi ini juga dipakai guna merancang tindakan berikutnya secara bersamasama.

Teknik pengumpulan data pada penelitian ini meliputi

\section{Observasi}

Tujuan observasi untuk mengetahui dan mendiskripsikan data hasil 2. Tes belajar pada aspek Afektif dan hasil belajar aspek Psikomorik.

Tes merupakan alat atau prosedur yang dipergunakan dalam rangka pengukuran dan penlaian hasil belajar aspek Kognitif.

\section{Dokumentasi}

Pada teknik pengumpulan data dokumentasi digunakan untuk mengetahui daftar nama siswa dan kehadiran siswa, silabus, RPP dan foto-foto kegiatan saat pembelajaran berlangsung yang menjadi subjek penelitian serta mengetahui nilai siswa sebelum dilakukan penelitian tindakan kelas.

Sugiyono (2015:148) Analisis data dilakukan berdasarkan tiga tahap, yaitu reduksi data yang merupakan proses penyederhanaan yang dilakukan melalui seleksi, pemfokusan, dan pengabstraksian data mentah menjadi informasi yang bermakna, display data (penyajian data) merupakan data yang sudah terorganisasi ini dideskripsikan dalam bentuk narasi, grafik maupun tabel, dan yang terakhir adalah penyimpulan yang merupakan proses pengambilan data secara lebih sederhana dalam bentuk pernyataan kalimat yang singkat dan padat tetapi mengandung pengertian yang luas.

Hasil belajar siswa dikatakan meningkat jika Ada perubahan hasil belajar secara berkelanjutan dari siklus pertama ke siklus kedua. Minimal 75\% siswa kelas $\mathrm{V}$ memenuhi kriteria ketuntasan minimal (KKM) dalam pembelajaran menulis puisi. Kriteria ketuntasan minimal (KKM) yang dimaksud adalah 75 .

Untuk mengetahui peningkatan hasil belajar siswa maka menggukan rumus sebagai berikut :

a) Hasil belajar Aspek Kognitif 
Syaiful, Implementasi Model Pembelajaran Think...

Indikator penilaiannya meliputi :

1) Kesesuaian judul dan tema dengan isi

2) Diksi dan gaya bahasa

3) Citraan/imaji

4) Rima

5) Amanat/pesan

Dengan rumus sebagai berikut :

Nilai $=\frac{\text { SkorPerolehan }}{\text { SkorMaksimal }} \times 100$

b) Hasil belajar Aspek Afektif

Indokator penilaiannya meliputi :

1) Menerima (A1);

2) Menganggapi (A2);

3) Menilai (A3);

4) Mengorganisasi (A4);

5) Menjadi karakter (A5).

Dengan rumus sebagai berikut :

Nilai $=\frac{\text { SkorPerolehan }}{\text { SkorMaksimal }} \times 100$

c) Hasil Belajar Aspek Psikomotorik

Indikator penilainya meliputi

1) Imitasi (P1);

2) Manipulasi (P2);

3) Presisi (P3);

4) Artkulasi (P4).

Dengan rumus sebagai berikut :

Nilai $=\frac{\text { SkorPerolehan }}{\text { SkorMaksimal }} \times 100$

\section{HASIL}

\section{Pra Tindakan}

Pembelajaran bahasa Indonesia materi keterampilan menulis puisi yang dilakasanakan dengan menggunakan metode pembelajaran ceramah dengan konsep pembelajaran yang berpusat pada guru belum berjalan efektif. Hal ini ditunjukkan dengan hasil belajar siswa yang rendah. Ketuntasan belajar klasikal pra tindakan pada aspek kognitif sebesar 45,33\%, dan ketuntasan aspek afektif sebesar 67,00\%, sedangakan ketuntasan klasikal aspek psikomotorik sebesar 64,50\%.

\section{Tindakan I}

Penerapan Think Talk Write (TTW) untuk meingkatkan hasil belajar (kognitif, afektif dan psikomotorik) mata pelajaran bahasa Indonesia di SDN Batu Belah Timur Kecamatan Dasuk kabupaten Sumenep pada Siklus I dengan tahapan-tahapan berikut ini

a) Perencanaan

Sebelum melaksanakan tindakan, peneliti menyiapkan perangkat pembelajaran yaitu RPP (Rencana Pelaksanaan Pembelajaran), materi pelajaran Bahasa Indonesia 


\section{Syaiful, Implementasi Model Pembelajaran Think...}

materi Menulis Puis.Kemudian peneliti menyiapkan alat atau media yang diperlukan.Untuk media pengamatan, peneliti menyiapkan Lembar Observasi untuk melihat bagaimana kondisi siswa di kelas ketika model pembelajaran Think Talk Write (TTW)diaplikasikan.Terakhir peneliti menyiapkan alat evaluasi berupa tes dalam bentuk karya puisi untuk mengetahui tingkat keberhasilan siswa dalam mengikuti kegiatan pembelajaran.

b) Pelaksanaan

Pada tahap pelaksanaan tindakan, langkah-langkah kegiatan pembelajaran yang dilakukan pertama kali setelah guru memasuki kelas yaitu guru memberikan salam, menanyakan kabar siswa dan dilanjutkan dengan presensi kehadiran siswa. Setelah dilakukan presensi, kondisi siswa sedikit ramai atau gaduh.Hasil dari presensi terdapat 20 siswa yang hadir mengikuti kegiatan pembelajaran.

Langkah kedua yaitu, menyampaikan garis besar pelaksanaan model pembelajaran yang akan digunakan oleh peneliti yaitu model Think Talk Write (TTW) dan bagaimana cara penilaiannya. Setelah peneliti menjelaskan, siswa tampaknya sudah mulai paham dengan model pembelajaran yang akan penelititerapkan. Setelah siswa sudah terlihat paham dengan penjelasan peneliti, kemudian peneliti membagikan bahan ajar berupa wacana kesusastraan, kumpulan puisi dan tata cara penulisan puisi. Siswa diminta untuk membaca dan membuat catatan kecil.Ketika siswa membuat catatan kecil inilah akan terjadi proses berpikir (Think). Setelah itu, siswa berusaha untuk menyelesaikan masalah tersebut secara individu.Kegiatan ini bertujuan agar peserta didik dapat membedakan atau menyatukan ide-ide yang terdapat pada bacaan untuk kemudian diterjemahkan ke dalam bahasa sendiri, selajutnya peneliti membagi siswa dalam kelompok kecil (3-5 siswa).Siswa berinteraksi dalam berkolaborasi dengan teman satu grup untuk membahas isi catatan dari hasil catatan (Talk).Dalam kegiatan ini mereka menggunakan bahasa dan kata-kata mereka sendiri untuk menyampaikan ide-ide dalam diskusi.Pemahaman dibangun melalui interaksinya dalam diskusi.Diskusi diharapkan dapat menghasilkan solusi atas masalah yang diberikan.Dari hasil diskusi, peserta didik secara individu merumuskan pengetahuan dan imajenasi dalam bentuk karya berupa puisi (Write) dengan kreatifitasnya sendiri.

c) Pengamatan

Selama implementasi tindakan, peneliti dan guru kelas melihat secara langsung bagaimana pelaksanaan pembelajaran Bahasa Indonesia materi menulis puisi dengan model pembelajaran Think Talk Write (TTW). Observasi tindakan dilakukan bersamaan dengan pelaksanaan tindakan.

Observasi dilakukan untuk mengetahui sejauh mana rencana intervensi tindakan telah dilaksanakan serta efek yang ditimbulkan dari pelaksanaan tindakan tersebut, baik bagi siswa, guru, maupun sistem pembelajaran secara keseluruhan.Melalui penerapan model pembelajaran Think Talk Write (TTW)respon siswa dalam mengikuti kegiatan pembelajaran sangat senang dan antusias. Hal ini sejalan dengan terjadinya peningkatan hasil belajar siklus I dibandikan dengan prasiklus.

Hasil belajar aspek kognitif Tindakan I adalah 70\% Sementara hasil belajar aspek afektif pada Tindakan I sebesar 79,52 \% Sedangkan hasil belajar aspek psikomotorik pada Tindakan I ketercapaian klasikal siswa mencapai rata-rata $88,00 \%$. 


\section{Syaiful, Implementasi Model Pembelajaran Think...}

d) Refleksi

Refleksi adalah evaluasi yang dilakukan peneliti dan observer. Setelah dilaksanakan uji instrumen Tindakan I terhadap proses pembelajaran dengan model pembelajaran Think Talk Write (TTW) maka ada beberapa hal yang peneliti temukan diantaranya adalah dalam pembentukan kelompok masih belum maksimal, proses berpikir siswa belum efektif, pembentukan kelompok yang berorientasi pada pertemanan karena diserahkan kepada siswa untuk memilih teman kelompoknya sendiri, banyak siswa yang kurang fokus pada diskusi kelompok, peran guru kurang masikmal karena hanya berperan sebagai pengamata, sehingga hasil belajar siswa masih banyak yang belum mencapai KKM.

\section{Tindakan II}

Berdasarkan hasil belajar dan rekfleksi Tindakan I bahwa banyak siswa yang belum mencapai Kreteria Ketuntasan Minimal (KKM) dan yang masih belum mencapai indikator keberhasilan serta beberapa kelemahan pada Tindakan I maka diperbaiki dengan langkah-langkah pada Tindakan II sebagai berikut :

a) Perencanaan

Sebelum melaksanakan tindakan, peneliti menyiapkan perangkat pembelajaran yaitu RPP (Rencana Pelaksanaan Pembelajaran), materi pelajaran Bahasa Indonesia materi Menulis Puisi.Kemudian peneliti menyiapkan alat atau media yang diperlukan.Untuk media pengamatan, peneliti menyiapkan Lembar Observasi untuk melihat bagaimana kondisi siswa di kelas ketika model pembelajaran Think Talk Write (TTW)diaplikasikan.Terakhir peneliti menyiapkan alat evaluasi berupa tes dalam bentuk karya puisi untuk mengetahui tingkat keberhasilan siswa dalam mengikuti kegiatan pembelajaran.

Sebagai perbaikan dari Tindakan I peneliti harus merencanakan alokasi waktu yang lebih tepat sehingga lebih terstruktur, pemilihan kelompok juga langsung dipandu oleh peneliti selain itu pelaksanaan pembelajaran yang semula didalam kelas pada Tindakan II pembelajaran akan dilakukan diluar kelas sehingga proses pembelajaran dapat lebih efektif dan menyenangkan.

b) Pelaksanaan

Pada fase ini, langkah pembelajaran yang dilkukan peneliti adalah mengajak siswa untuk melakukan proses pembejaran diluar kelas. Konsep pembelajaran ini dipilih karena peneliti menginginkan proses pembelajaran lebih menyenangkan dan menjadikan alam sekitar sebagai bagaian dari proses belajar siswa, sehingga proses kreatif siswa lebih maksimal. Setelah siswa kondusif diluar kelas maka peneliti melakukan presensi kehadiran siswa. Setelah presensi siswa, guru mengkondisikan kelas agar siswa tidak gaduh dan lebih siap untuk menerima pelajaran. Kemudian peneliti sedikit mengingatkan materi yang telah lalu serta memberikan apersepsi atau garis besar dari materi yang akan diberikan pada pertemuan tersebut.

Langkah berikutnya peneliti membentuk kelompok kecil, setiap kelompok terdiri dari 5 orang siswa, pengelompokan ini langsung dipandu oleh oleh peneliti, setelah itu peneliti memberikan materi tentang puisi, unsur-unsur puisi dan cara menulis puisi. Siswa dipersilakan untuk membaca dan membuat cacatan (Think) dari bahan bacaan tersesebut, setelah proses berpikir siswa maka berikutnya siswa diminta untuk mendiskusikan (Talk) hasil dari proses berpikir tersebut dalam kelompok mereka. Siswa harus menulis (Write) beberapa hal yang telah mereka 


\section{Syaiful, Implementasi Model Pembelajaran Think...}

diskusikan dan serta mengambangkan dalam bentuk karya puisi yang dibantu dengan imajenasi berdasarkan apa yang siswa lihat dan nikmati diluar kelas.

Diakhir pelajaran peneliti memberikan kesimpulan materi serta memberikan apresiasi kepada siswa karena keaktifannya mengikuti kegiatan pembelajaran. Sebelum meninggalkan kelas guru mengucapkansalam.

c) Pengamatan

Seperti yang telah dilakukan pada tindakan 1, pengamatan jalannya proses pembelajaran kembali dilakukan. Peneliti dan observer yang mengamati jalannya proses pembelajaran melihat apakah tindakan-tindakan berjalan sesuai dengan apa yang telah direncanakan.

Hasil penelitian pada tindakan II menunjukkan bahwa pelaksanaan tindakan sudah berjalan sesuai rencana karena terjadi peningkatan hasil belajar yang terlihat dari hasil belajar.

Tindakan II menunjukkan peningkatan hasil belajar bahasa Indonesia materi menulis puisi siswa kelas V SDN Batu Belah Timur I kecamtan Dasuk kabupaten Sumenep melalui implementasi model pembelajaran Think Talk Write (TTW). Presentase Ketercapaian kelasikal Hasil belajar aspek kognitif sebesar 90\%, dan aspek afektif 98,33\% sedangkan aspek psikomotorik sebesar $98 \%$.

d) Refleksi

Dari hasil evaluasi terhadap hasil pengamatan yang telah dilakukan pada Tindakan II, dapat dikatakan bahwa tindakan yang telah dilakukan sudah sesuai dengan perencanaan yang telah disusun sebelumnya dan telah mencapai hasil belajar yang telah diharapkan serta mencapai indikator keberhasilan.3.

\section{PEMBAHASAN}

Pada penelitian tindakan kelas yang dilaksanakan di SDN Batu Belah Timur Kecamatan Dasuk ini diawali dengan pelakasanaan Pra Tindakan, dilanjutkan dengan pelaksanaan tindakan I dan tindakan II sebagaimana telah dipaparkan dalam hasil penelitian diatas.Implementasi strategi pembelajaran kooperatif tipe Think Talk Write (TTW) sangat dipengaruhi oleh kesiapan guru dalam merancang dalan melaksanakan proses pembelajaran.

Yamin dan Ansari (2008) Think Talk Write (TTW) pada dasarnya dibangun melalui berpikir, berbicara dan menulis. Alur kemajuan Think Talk Write dimulai dari keterlibatan siswa dalam suatu dialog dengan dirinya sendiri, selanjutnya berdiskusi dan membagi (sharing) dengan temannya sebelum menulis dan akhirnya melalui diskusi siswa dapat menuliskan kembali hasil pemikirannya tersebut.

Dengan menerapkan Think Talk Write (TTW) pada pembelajaran bahasa Indonesia materi menulis puisi siswa kelas V SDN Batu Belah Timur I Kecamatan Dasuk kabupaten Sumenep maka terjadi peningkatan hasil belajar dari setiap tindakan yang dilakukan oleh peneliti.

Kunandar (2015) Hasil Belajar adalah kompetensi atau kemampuan tertentu baik kognitif, afektif maupun psikomotorik yang dicapai atau dikuasai peserta didik setelah mengikuti proses belajar mengajar.

Perencanaan dan pelaksanaan Tindakan I cukup baik, hal ini terlihat dari Hasil belajar aspek kognitif Tindakan I adalah 70\% Sementara hasil belajar aspek afektif pada Tindakan I sebesar 79,52 \% sedangkan hasil belajar aspek psikomotorik pada tindakan I 


\section{Syaiful, Implementasi Model Pembelajaran Think...}

ketercapaian klasikal siswa mencapai rata-rata $88,00 \%$. Hanya saja ada beberapa kelemahan dalam pelaksanaan Tindakan I yaitu ada beberapa hal yang peneliti temukan diantaranya adalah dalam pembentukan kelompok masih belum maksimal, proses berpikir siswa belum efektif, pembentukan kelompok yang berorientasi pada pertemanan karena diserahkan kepada siswa untuk memilih teman kelompoknya sendiri, banyak siswa yang kurang fokus pada diskusi kelompok, peran guru kurang masikmal karena hanya berperan sebagai pengamat, sehingga hasil belajar siswa masih banyak yang belum mencapai KKM.

Proses pengelompokan yang belum maksimal pada Tindakan I, karena diserahkan kepada siswa sehingga kondisi kelas gaduh, dan alokasi waktu banyak terbuang percuma. Pada Tindakan II peneliti mengambil alih pembentukan kelompok sehingga alokasi waktu tidak terbuang percuma dan kelas menjadi kondusif.

Tindakan I peran peneliti belum maksimal karena peneliti berperan sebagai pengamat sehingga peneliti didorong untuk lebih melakukan pendampingan pada Tindakan II dangan cara melakukan pemantauan, pengarahan dan memberikan motivasi kepada siswa untuk melakukan proses berpikir, berdikusi dan menulis.

Pada Tindakan I sumber belajar masih terbatas, karena pembelajaran dilakukan didalam kelas, siswa masih mengandalkan bahan ajar dari guru, dan tidak bisa membuka cakrawala imajenasi dalam mengarang karya berbentuk puisi, hal ini menjadi dasar pelakasanaan pembelajaran Tindakan II, bahwa siswa membutuhkan cakrawala alam sekitar untuk dapat berpikir, berdiskusi dan melahirkan tulisan dalam bentuk karya puisi.

Berikut perbandingan hasil belajar (kognitif, afektif dan psikomotorik) pembelajaran Bahasa Indonesia materi menulis Puisi siswa kelas V SDN Batu Belah Timur I kecamatan Dasuk kabupaten Sumenep.

\section{Grafik 1. Perbandingan hasil belajar aspek Kognitif}

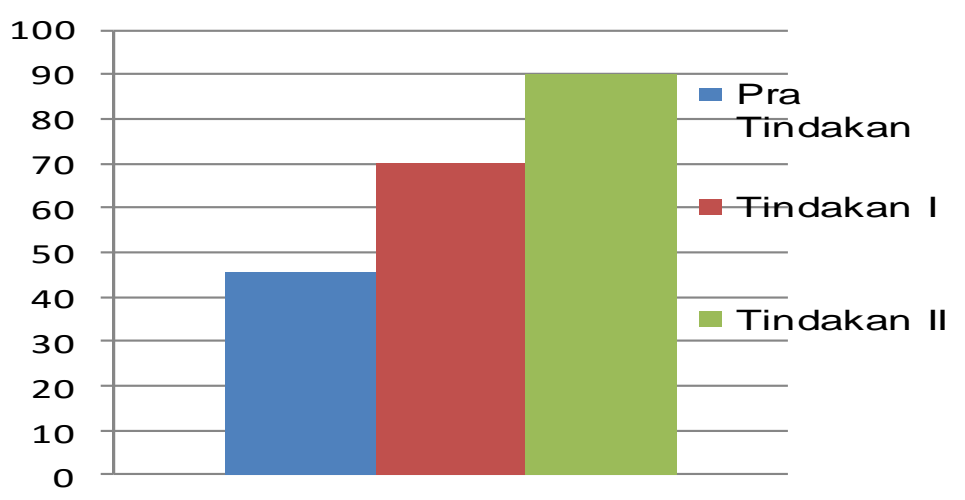

Analisis tes pra tindakan menunjukkan jumlah skor keseluruhan sebesar 272 dengan jumlah skor maksimumnya adalah 600. Sedangkan Presentase ketercapaian secara klasikal pada Pra Tindakan memperoleh ketercapaian 45,33 \% dengan rician pemerolehan jumlah skor 906,67 dikali nilai ideal 100 dan dibagi jumlah skor maksimum sebesar 2000. yang memperoleh nilai antara 30-39 sebanyak 3 siswa dengan presentase $20 \% .8$ siswa memperoleh nilai anatara $40-49$ dengan presentase $40 \% .35 \%$ 


\section{Syaiful, Implementasi Model Pembelajaran Think...}

siswa mendapat nilai antara 50-59 sejumlah 7 orang. Sedangkan 1 siswa mendapat nilai 60-69 dengan presentase 5\%. Dalam Pra Tindakan ini tidak ada siswa yang mencapai standar kelulusan minimal (SKM).

Analisis tes (aspek kognitif) tindakan I menunjukkan jumlah skor keseluruhan sebesar 420 dengan jumlah skor maksimumnya adalah 600. Sedangkan Presentase ketercapaian secara klasikal dalam penelitian pada tindakan I memperoleh ketercapaian $70 \%$ dengan rincian pemerolehan jumlah skor 1400 dikali nilai ideal 100 dan dibagi jumlah skor maksimum sebesar 2000.

Presentase keberhasilan subyek penelitian pada tindakan I menunjukkan bahwa subyek penelitian yang memperoleh nilai antara 60-69 sebanyak 8 siswa dengan presentase $40 \%$.Sedangkan $60 \%$ atau sejumlah 12 orang siswa mendapat nilai antara 70 79

Setelah dilakukan analisis hasil tes (aspek kognitif) maka dapat dilihat peningkatan yang signifikan. Hasil tes yang dilakukan pada pra tindakan hanya 45,33\% ketercapaian klasikal siswa, dan hal ini mengalami peningkatan ketika peneliti melakukan penelitian pada tindakan I, hasil ketercapain Tindakan I adalah 70\%. Terdapat peningkatan hasil belajar aspek kognitif dari Pra Tindakan ke Tindakan I sebesar 24,67\%.

Sedangkan analisis tes aspek kognitif tindakan II menunjukkan bahwa jumlah skor yang diperoleh secara akumulatif sebesar 540, jumlah skor maksimum 600 menghasilakan 90\%. Sedangkan presentasi ketercapaian secara klasikal diperoleh jumlah 1800 dikali jumlah nilai ideal 100 dan dibagi jumlah skor maksismum 2.000 mengahsilakan presentase ketercapaian sebesar $90 \%$.

Presentase keberhasilan siswa aspek kognitif Tindakan II menunjukkan hasil yang lebih signifikan jika dibandingkan dengan tindakan I. pada tindakan ini 7 siswa memperoleh nilai antara 80-89 dengan presentase 35\%. Sedangkan sisanya sebanyak 13 siswa dengan presentase 65\% mendapat nilai tertinggi antara 90-100.

Berdasarkan gambar 1. diagram perbandingan hasil belajar aspek kognitif maka dapat dilihat peningkatan yang signifikan. Hasil tes yang dilakukan pada pra tindakan hanya 45,33\% ketercapaian klasikal siswa, dan hal ini mengalami peningkatan ketika peneliti melakukan penelitian pada tindakan I, hasil ketercapain Tindakan I adalah $70 \%$. Terdapat peningkatan hasil belajar dari Pra Tindakan ke Tindakan I sebesar 24,67\%.

Presentase ketercapaian pada Tindakan II menunjukkan peningkatan yang signifikan dibandingkan dengan tindakan sebelumnya, Tingkat ketercapaian tindakan II sebesar 90\%. Terdapat peningkatan presentase pada tindakan II dibandingkan ketercapaian dari pra tindakan sebesar 44,67\%, sedangkan dibandingkan dengan tingkat ketercapaian klasikal pada tindakan II sebesar $30 \%$. 
Syaiful, Implementasi Model Pembelajaran Think...

Grafik 2. Perbandingan Rata-rata Hasil Belajar Aspek Afektif Siswa

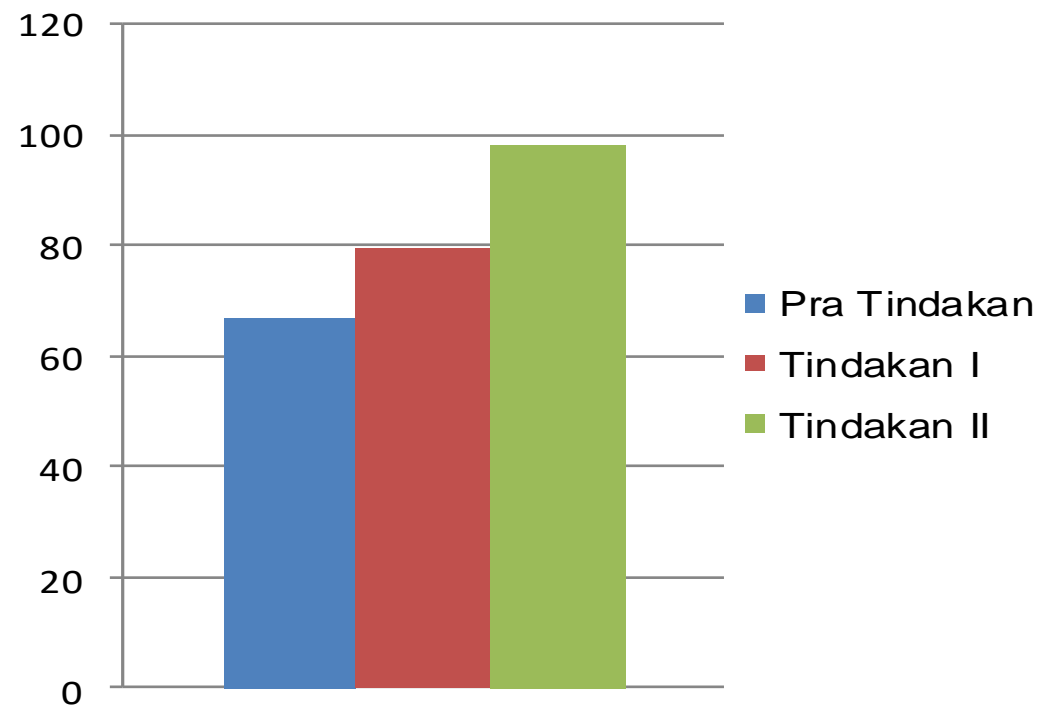

Pada diagram di atas menunjukkan adanya peningkatan rata-rata nilai afektif dari kegiatan pra tindakan, tindakan I, sampai dengan tindakan II. Rata-rata nilai afektif pada pra tindakan menunjukkan 67,00, dengan rincian siswa yang mendapat nilai afektif 50-59 ada 6 siswa, yang mendapat nilai afektif 60-69 ada 6 siswa, yang mendapat nilai afektif 70-79 ada 2 siswa, yang mendapat nilai afektif 80-89 ada 4 siswa, yang mendapat nilai afektif 90-99 tidak ada, dan yang mendapat nilai afektif 100 ada 2 siswa.

Setelah dilakukan tindakan I rata-rata nilai afektif meningkat menjadi 79,52. siswa yang mendapat nilai afektif 50-59 tidak ada, yang mendapat nilai afektif 60-69 ada 2 siswa, yang mendapat nilai afektif 70-79 ada 10 siswa, yang mendapat nilai afektif 80-89 ada 3 siswa, yang mendapat nilai afektif 90-99 tidak ada, dan yang mendapat nilai afektif 100 ada 6 siswa.

Hasil belajar aspek Afektif pada Tindakan II siswa yang mendapat nilai afektif 50-59 tidak ada, yang mendapat nilai afektif 60-69 tidak ada, yang mendapat nilai afektif 70-79 tidak ada, yang mendapat nilai afektif 80-89 ada 2 siswa, yang mendapat nilai afektif 90-99 tidak ada, dan yang mendapat nilai afektif 100 ada 18 siswa. Ratarata nilai afektif siswa pada kegiatan tindakan II yakni 98,33.

Berdasarkan gambar 2. Diagram Perbandingan Rata-Rata Hasil Belajar aspek Afektif menunjukkan adanya peningkatan rata-rata nilai afektif dari kegiatan pra tindakan, tindakanI, sampai dengan tindakan II. Rata-rata nilai afektif pada pra tindakan menunjukkan 67,00, setelah dilakukan tindakan I rata-rata nilai afektif meningkat menjadi 79,52 dan mengalami peningkatan menjadi 98,33 pada tindakan II. 
Syaiful, Implementasi Model Pembelajaran Think...

\section{Grafik 3. Perbandingan Rata-rata Hasil Belajar Aspek Psikomotor Siswa}

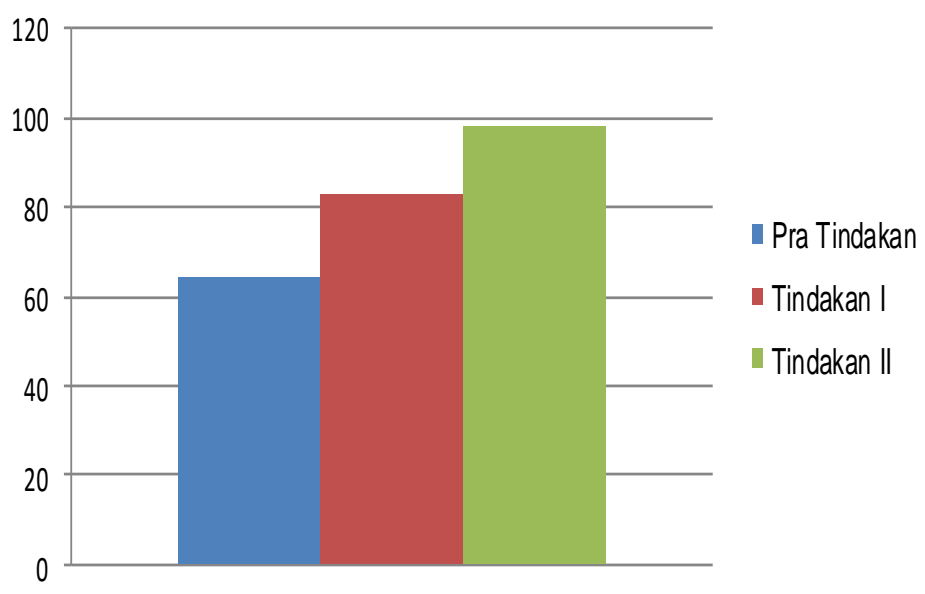

Pada diagram di atas menunjukkan adanya peningkatan rata-rata nilai psikomotor dari kegiatan pra tindakan, tindakan I, sampai dengan tindakan II. Rata-rata nilai psikomotor pada pra tindakan menunjukkan 64,50, dengan rincian siswa yang mendapatkan nilai keterampilan 50-59 ada 12 siswa, yang mendapat nilai keterampilan 60-69 ada 2 siswa, yang mendapat nilai keterampilan 70-79 tidak ada, yang mendapat nilai keterampilan 80-89 ada 4 siswa, yang mendapat nilai keterampilan 90-99 tidak ada, dan yang mendapat nilai keterampilan 100 ada 2 siswa.

Setelah dilakukan tindakan I rata-rata nilai psikomotor meningkat menjadi 83,00. siswa yang mendapatkan nilai keterampilan 50-59 tidak ada, yang mendapat nilai keterampilan 60-69 ada 8 siswa, yang mendapat nilai keterampilan 70-79 tidak ada, yang mendapat nilai keterampilan 80-89 ada 3 siswa, yang mendapat nilai keterampilan 90-99 tidak ada,dan yang mendapat nilai keterampilan 100 ada 9 siswa.

Mengalami peningkatan menjadi 98,00 pada tindakan II dengan rincian sebagai berikut siswa yang mendapatkan nilai keterampilan 50-59 tidak ada, yang mendapat nilai keterampilan 60-69 tidak ada, yang mendapat nilai keterampilan 70-79 tidak ada, yang mendapat nilai keterampilan 80-89 ada 2 siswa, yang mendapat nilai keterampilan 90-99 tidak ada, dan yang mendapat nilai keterampilan 100 ada 18 siswa.

Berdasarkan Gambar 3. Digram Perbandingan Rata-Rata hasil belajar aspek Psikomotorik menunjukkan adanya peningkatan rata-rata nilaipsikomotor dari kegiatan pra tindakan, tindakanI, sampai dengan tindakan II. Rata-rata nilai psikomotor pada pra tindakan menunjukkan 64,50, setelah dilakukan tindakan I rata-rata nilai psikomotor meningkat menjadi 83,00 dan mengalami peningkatan menjadi 98,00 pada tindakan II.

Peningkatan hasil belajar pada tiga aspek tersebut adalah hasil dari implementasi model pembelajaran Think Talk Write (TTW) yang berjalan efektif. Efektifitas tersebut terlihat pada proses perencanaan pembelajaran yang baik sehingga dapat dilaksanakan dengan lancar.

\section{KESIMPULAN}

Implementasi model pembelajaran Think Talk Write pada pembelajaran Bahasa Indonesia kelas V Sekolah Dasar dapat meningkatan hasil belajar menulis puisi, hal ini terbukti bahwa terdapat peningkatan hasil belajar dari setiap tindakan. Pra tindakan 


\section{Syaiful, Implementasi Model Pembelajaran Think...}

memperoleh tingkat ketercapaian klasikal pada aspek kognitif sebesar 45,33\%, dan tindakan I sebesar 70\% sedangkan pada tindakan II sebesar 90\%. Aspek Rata-rata nilai afektif pada pra tindakan menunjukkan 67,00, setelah dilakukan tindakan I rata-rata nilai afektif meningkat menjadi 79,52 dan mengalami peningkatan menjadi 98,33 pada tindakan II, sedangkan aspek psikomotorik rata-rata nilai psikomotor pada pra tindakan menunjukkan 64,50, setelah dilakukan tindakan I rata-rata nilai psikomotor meningkat menjadi 83,00 dan mengalami peningkatan menjadi 98,00 pada tindakan II.

\section{DAFTAR RUJUKAN}

Arikunto, S. 2009. Penelitian Tindakan Kelas. Jakarta: PT. Bumi Aksara

Kunandar. 2015. Penilaian Autentik (Penilaian Hasil Belajar Peserta Didik Berdasarkan Kurikulum 2013). Jakarta : PT Raja Garfindo Persada.

Lubis, M. 1997. Sastra dan Tekhniknya. Jakarta : Obor Indonesia.

Shoimin, A. 2014. 68 Model Pembelajaran Inovatif dalam Kurikulum 2013. Yogyakarta : Ar-Ruzz Media.

Sugiyono. 2015. Metode Penelitian Kuantitatif Kualitatif dan R\&D. Bandung: Alfabeta.

Yamin, M. s\& Ansari, B., I. 2008. Taktik Mengembangkan Kemampuan Individual Siswa. Jakarta: Gaung Persada Pers. 